\title{
AMH Gene
}

National Cancer Institute

\section{Source}

National Cancer Institute. AMH Gene. NCI Thesaurus. Code C101735.

This gene plays a role in gonad development. 